\title{
IVC Filter Implantation in Renal Mass with IVC Thrombus, is it Beneficial? A Case Report and Review of Literature
}

\author{
Waheed Zaman ${ }^{3 *}$, Ranen Biswas ${ }^{1}$, Nazim Uddin Mohammad Arif ${ }^{1}$ and Reaza AQM ${ }^{2}$ \\ ${ }^{1}$ Department of Urology \& Renal Transplantation, Apollo Hospitals, Bangladesh \\ ${ }^{2}$ Department of Clinical \& Interventional Cardiology, Apollo Hospitals, Bangladesh \\ ${ }^{3}$ Department of Urology, MAX Hospital, India
}

Submission: November 28, 2016; Published: February 06, 2017

*Corresponding author: Dr. Waheed Zaman, Department of Urology, MAX Hospital, India, Tel: +8801711363588;

E-mail:wzaman.2009@gmail.com

\begin{abstract}
Renal mass is the most common tumor to extend into the IVC. IVC thrombectomy is the only treatment of choice of IVC thrombus, it may be proceed after new adjacent therapy or IVC filter placement. IVC filter implantation to prevent pulmonary embolism of tumor thrombus preoperative or immediate undergoing Radical nephrectomy with inferior vena cava (IVC) thrombectomy.

Keywords: Renal mass; IVC thrombus; Retrieval venous filter; Transcatheter arterial embilization

Abbreviations: IVC: Inferior Vena Cava; TAE: Transcatheter Arterial Embilization
\end{abstract}

\section{Introduction}

Renal mass extends into the renal vein and inferior vena cava (IVC) as a thrombus of tumor in approximately $4-10 \%$ of all patients with this disease [1]. There are few other tumors also which may cause IVC thrombus are Wilma's tumor, Adrenal tumor, Ovarian tumor, Testicular tumor, Hepatocarcinoma, Soft tissue leomyosarcoma, Pheochromocytoma, Angiomyolipoma. When the surgery provides the only curative option, but its complex procedure needs participation of multi-disciplinary team. Usual Radical nephrectomy with IVC thrombectomy may or may not develop pulmonary embolism. After IVC filter implantation if we can perform surgical procedure more safely, preventing tumor embolism.

\section{Case Report}

A 58 years old, female patient presented to us with the history of right lumber pain and intermittent hematuria for more than one month. She was a known case of hypertension, dyslipidaemia, hypothyroidism. Initially, she was investigated and was diagnosed as a case of Right renal mass with inferior vena cava (IVC) thrombus (Figure 1). In our evaluation her $\mathrm{Hb}$ $9.7 \mathrm{gm} / \mathrm{dl}$, serum creatinine $2.02 \mathrm{mg} / \mathrm{dl}$ and chest x-ray was normal.

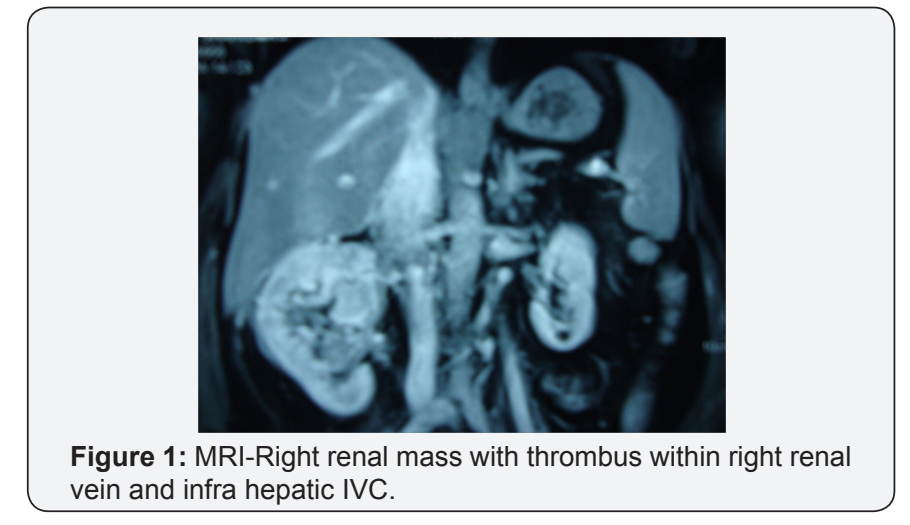

We did upper abdomen MRI which revealed large soft tissues mass within right kidney with thrombus within right renal vein and infra hepatic IVC (Figure 2) and Upper abdomen color Doppler ultra sonogram showed Right renal mass, right renal vein and IVC thrombus, Regular bone scan showed Non-specific abnormalities (Figure 3). We took the cardiac consultation regarding IVC thrombus before surgery and their opinion was to place IVC filter to prevent pre-operative thromboembolic complications. Our Interventional cardiologist performed right 
tumor emboligation and suprarenal IVC filter placement (Figure 4). Post IVC filter implantation abdominal veins color Doppler ultra sonogram showed that thrombus of about $55 \times 28 \times 38 \mathrm{~mm}$ is seen in upper IVC below the filter with focal dilatation of its lumen causing near occlusion. Venous filter is seen in retro hepatic IVC just proximal to thrombus below hepatic vein. Flow through IVC filter was patent. After 48 hours we performed right radical nephrectomy with IVC thrombectomy under epidural + general anesthesia without any complications. We discharged the patient on seventh post operative day. There was no evidence of peri or post procedure complications.

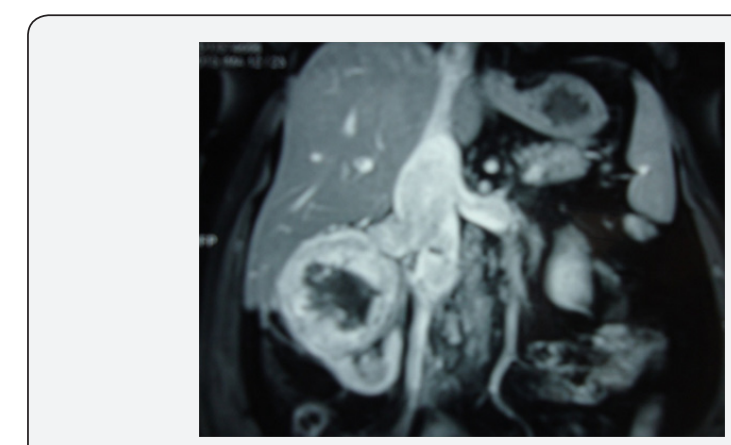

Figure 2: MRI-Right renal mass with thrombus within right renal vein, infra hepatic IVC and left renal vein.
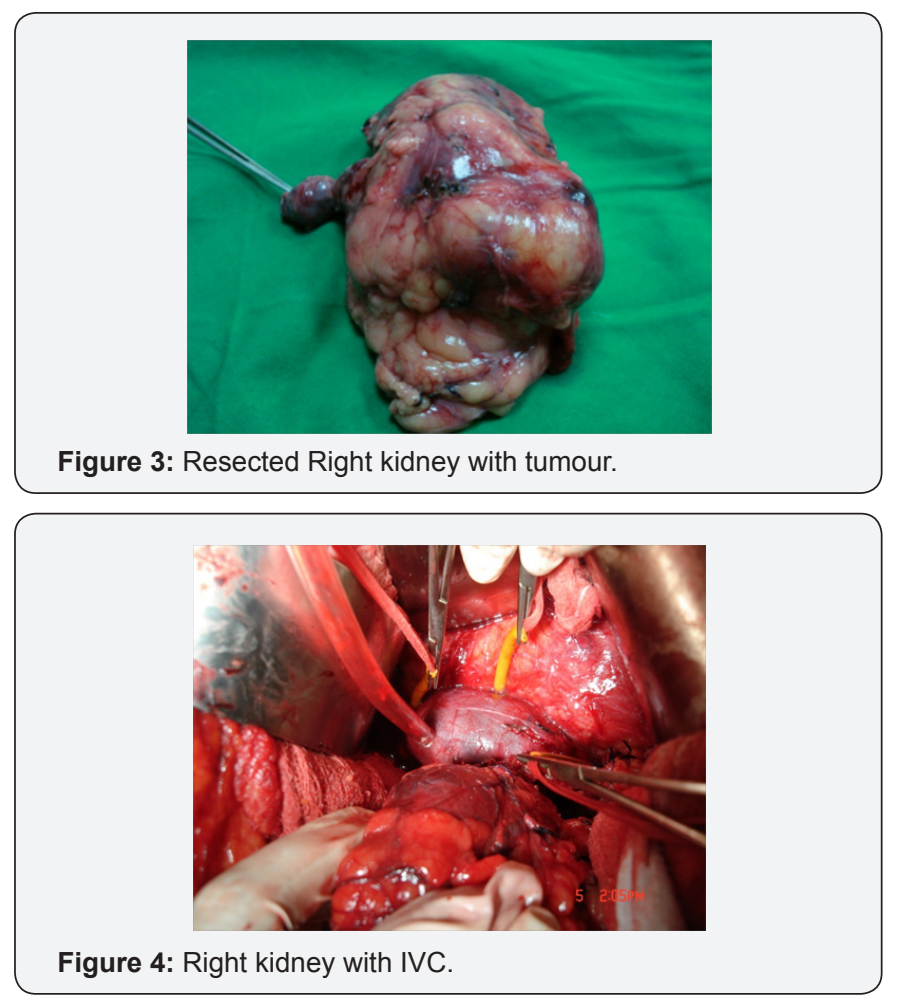

\section{Discussion}

The incidence of renal tumor with IVC thrombus is around $4-10 \%$ in various series. Radical Nephrectomy with IVC thrombectomy is a challenging job but with multi-specialty team approach good results can be achieved. Renal tumor with IVC thrombus is one of the greatest challenges for urologists because of its surgical management [1]. In renal cell carcinoma with venacaval thrombus, radical nephrectomy and vena caval thrombectomy provides satisfactory surgical outcome in select groups of patients. Prior knowledge of cephalad extension of the tumor thrombus helps in deciding the technique for thrombectomy [2,3]. Patient with metastatic renal cell carcinoma have a poor prognosis, as an associated 5 year mortality rate ranging from $80 \%$ to $100 \%$. However, there are some patients who, for unexplained reasons, have prolonged survival with metastatic disease. Carrafiello G, et al. [4] showed also 100\% feasibility in their procedure.

All filters were correctly deployed in the suprarenal tract of the IVC and resection of RCC performed in all patients without peri or post procedural complications. Retrieval venous filter successfully implanted in retro hepatic IVC just proximal to thrombus. The patient tolerated the procedure well.

There was no evidence of preoperative and immediate during surgery complications noted especially pulmonary embolism. Before performing radical nephrectomy with IVC thrombectomy IVC filter implantation is safer and feasible option. IVC filter implantation have a great role in Renal mass with IVC

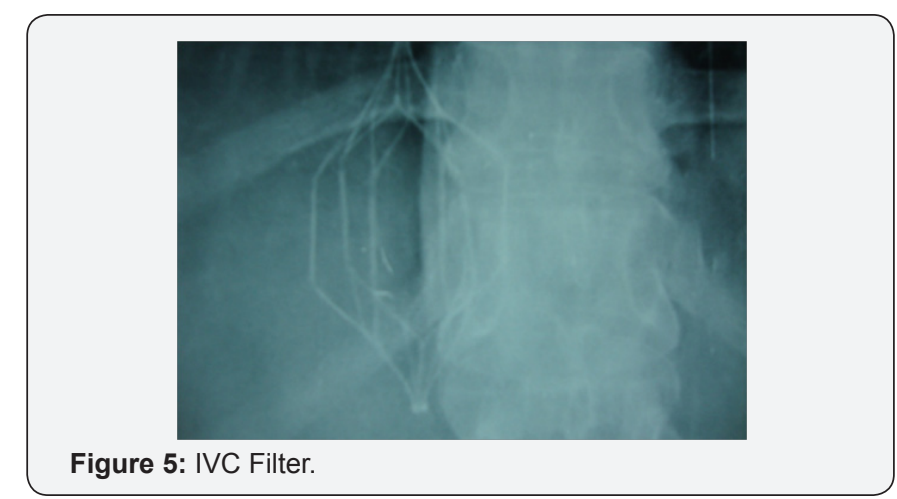

Thrombus. It can prevent pulmonary tumor emboli. Hirota $\mathrm{S}$, et al. [5] showed that suprarenal IVC filter (Figure 5) placement prior to transcatheter arterial embilization (TAE) for advanced renal cell carcinoma invading the renal vein or the IVC is an effective procedure to prevent pulmonary thromboemboli.

IVC filter usually used to prevent pulmonary tumor emboli in high risk patient (Figure 6). IVC filter can be done through femoral approach if IVC is clear of any thrombus. If thrombus is present in IVC, then procedure is done through right jugular venous approach. In this case as huge thrombus burden seen in IVC above and at the level of renal vein, so the procedure was done through right jugular successfully and filter was placed above renal vein and IVC thrombus. It is a rare event as usually IVC filter placement done below renal vein (Figure 7). It was the first case in Bangladesh. As usual the filter cane retrieved when the need of the IVC filter will over. We used Opt ease retrievable vena cava filter, Cords, Johnson \& Johnson. In fact IVC filter implantation is costly but it can reduce mortality and surgeon can proceed safely. 

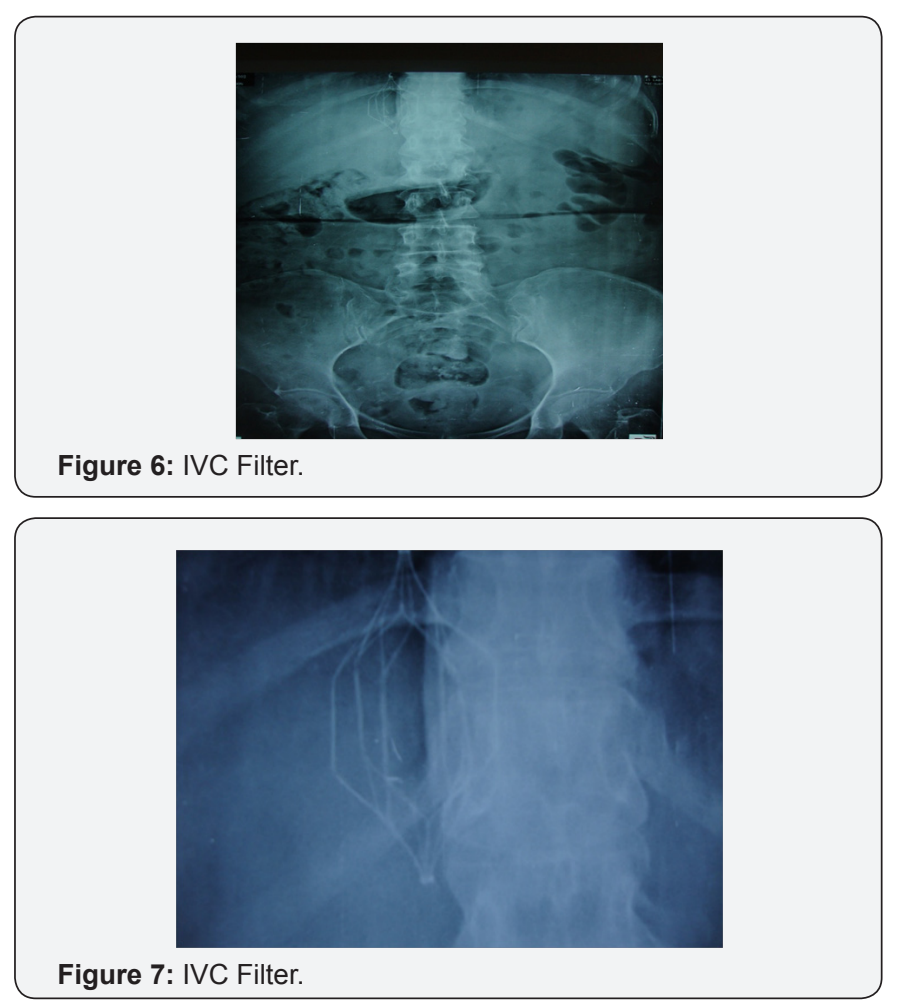

\section{Conclusion}

Suprarenal IVC filter placement prior to tumor embolization for advanced renal cell carcinoma invading renal vein or the IVC is an effective and beneficial procedure to prevent pulmonary thromboemboli and may contribute to longer survival.

\section{References}

1. Viswajeet singh, Wahid Zaman, Anant Kumar, Rakesh Kapoor, Aneesh Srivastava (2004) Renal cell carcinoma with tumor thrombus extension to inferior vena cava: SGPGIMS experience. Indian Journal of Urology 20(2): 90-94.

2. Lineham WM, Shipley WU, Longo DL (1993) Cancer of the kidney and ureter. In: DeVita VT, Helman S, Rosenberg SA (eds.) Cancer. Principles and practice of oncology. USA, pp: 1023-1051.

3. DeKemion JB, Ramming KP, Smith RB (1978) The natural history of metastatic renal cell carcinoma: a computer analysis. J Urol 120(2): 148-152.

4. Carrafiello G, Mangini M, Fontana F, Leradi AM, Di Massa A, et al. (2012) Suprarenal inferior vena cava filter implantation. Radio Med 117(7): 1190-1198.

5. Hirota S, Matsumoto S, Yoshikawa T, Tomita M, Sako M, et al. (1998) Inferior vena cava filter placement for prevention of pulmonary tumor emboli of renal cancer with renal vein or vena caval tumor thrombus: prophylactic usage prior to transcatheter arterial embolization. Radiat Med 16(5): 335-339.

\section{Your next submission with Juniper Publishers will reach you the below assets}

- Quality Editorial service

- Swift Peer Review

- Reprints availability

- E-prints Service

- Manuscript Podcast for convenient understanding

- Global attainment for your research

- Manuscript accessibility in different formats

( Pdf, E-pub, Full Text, Audio)

- Unceasing customer service

Track the below URL for one-step submission https://juniperpublishers.com/online-submission.php 